\title{
AB Borç Krizinin Türkiye Ekonomisini Etkileme Kanallarının Karşılaştırmalı Üstünlüğü
}

\author{
İsmail ÇEVIŞ (https://orcid.org/0000-0001-6246-8707), Department of Economics, Pamukkale University, \\ Turkey; e-mail: icevis@pau.edu.tr \\ Reşat CEYLAN (https://orcid.org/0000-0003-3727-6644), Department of Economics, Pamukkale University, \\ Turkey; e-mail: rceylan@pau.edu.tr
}

Nihal YAYLA (https://orcid.org/0000-0002-0647-5088), Department of Economics, Pamukkale University, Turkey; e-mail: nyayla@pau.edu.tr

\section{The Comparative Advantage of Contagion Channels of EU Debt Crisis to Turkish Economy}

\begin{abstract}
In this study, examining the contagion channels of EU debt crisis to Turkey, a financial fragility index is composed for the period of 2004:Q1-2014:Q3 to represent the debt crises. The relationship between this index and capital and finance channel (IIP), foreign trade channel (TTV), expectations channel (CCI and RCI) was analyzed by ARDL (Bound Test) method. Findings illustrates that there is a long run relationship between financial fragility index, real sector confidence index, trade volume and international investment position and that direction of the causality is from financial fragility index to other variables. As a result, EU debt crisis affects Turkey from all three channels, but the expectations channel has a comparative advantage.

Keywords

EU Debt Crisis, Financial Fragility index, Capital and Finance Channel, Foreign Trade Channel, Expectation Channel, ARDL.

JEL Classification Codes : $\quad$ C13, F41, F62, G01, O57.

\section{Öz}

AB borç krizinin Türkiye'ye yayılma kanallarının incelendiği çalışmada borç krizini temsil etmek üzere 2004:Q1-2014:Q3 dönemi için bir finansal kırılganlık endeksi oluşturulmuştur. Bu endeks ile sermaye ve finans kanalı (IIP), dış ticaret kanalı (TTV) ve beklentiler kanalı (CCI ve RCI) arasındaki ilişki ARDL (Sınır Testi) yöntemi ile analiz edilmiştir. Bulgular, finansal kırılganlık endeksi ile reel kesim güven endeksi, ticaret hacmi ve uluslararası yatırım pozisyonu arasında uzun dönemli bir ilişki olduğunu ve ilişkinin yönünün finansal kırılganlık endeksinden diğer üç değişkene doğru olduğunu göstermektedir. Sonuç olarak, borç krizi her üç kanaldan da Türkiye'yi etkilemekte ancak beklentiler kanalı karşılaştırmalı üstünlüğe sahip bulunmaktadır.
\end{abstract}

Anahtar Sözcükler $\quad$ : AB Borç Krizi, Finansal Kırılganlık Endeksi, Sermaye ve Finans Kanalı, Dış Ticaret Kanalı, Beklentiler Kanalı, ARDL. 


\section{Giriş}

Sermaye hareketlerinin serbestleşmesi ile birlikte özellikle büyük ekonomilerde baş gösteren krizler, küresel ortama kolaylıkla yayılır olmuştur. Küresel finansal kriz de nedenleri ve etkileri bakımından ciddi ve süregelen yansımalar ortaya çıkarması açısından oldukça önemlidir. Dolayısıyla küresel kriz, gelişimi ve etkileri açısından hem dünyada hem de ülkemizde önemli bir tartışma alanı yaratmıştır.

Ekonomi yazınında genel olarak finansal kriz, piyasalarda ortaya çıkan bozulmaların finansal kurumların performansını olumsuz bir biçimde etkileyerek tüm ekonomiye yayılması sonucunda ödeme sistemlerinin bozulması ve kaynakların etkin dağılımının engellenmesi olarak tanımlanmaktadır. Mishkin (2000)'e göre finansal krizler, ters seçim ve ahlaki tehlike sorunlarının giderek kötüleşmesi nedeniyle verimli yatırım olanaklarına sahip finansal piyasaların fon aktarma etkinliklerini kaybetmeleriyle ortaya çıkan doğrusal olmayan bir bozulmadır. Amerika Birleşik Devletleri'nde başlayan ve tüm dünya ekonomilerine yayılan 2008 finansal krizi de nitelikleri açısından bu kapsamda değerlendirilebilir.

2008 finansal krizinin ilk işaretleri aslında 2006 yllının ikinci çeyreğinde konut piyasasındaki bozulmalarla ortaya çıkmaya başlamıştır. Nitekim ABD konut ve finansal piyasalarında 2006 yılının sonları ile 2007 yılının başlarında görülen birkaç büyük kuruluşun iflas1 (Lehman Brothers, Merrill Lynch ve Amerikan International Group vb,) krizin ilk olayları olmuştur (Berberoğlu, 2011).

Murphy (2008), Alantar (2008), Işı1k ve Tönen (2008), Crotty (2009), Rose ve Spiegel (2009) ve Acharya ve Richardson (2009)'a göre 2008 finansal krizinin ortaya çıkmasındaki temel nedenler genel olarak şu şekilde sıralanmaktadır:

- Likidite bolluğu ve özensiz krediler,

- Menkul kıymetleştirme ile riskin bir kurumdan diğerine aktarılmasının kolaylaşması,

- Saydamlık eksikliği,

- Derecelendirme kuruluşlarının sübjektifliği,

- Düzenleyici ve denetleyici kuruluşların problem tespitinde geç kalması ve çözüm üretememesi,

- Finansal yapıdaki değişim ve faiz oranlarındaki uyumsuzluklar,

- Mortgage kredilerinin yapısının bozulması,

- Finansal istikrarsizlık,

- Finansal liberalizasyon (finansal serbestleşme ile finansal denetimin azalmasi).

ABD mortgage piyasalarında başlayan ve daha sonra likidite krizine dönüşen sorun, ABD bankalarının borç verme riskini küresel finansal piyasalar arasındaki sıkı bağlantılar aracılığıla yabancı yatırımcılara aktarması sonucunda başta Avrupa olmak üzere tüm 
dünyaya yayılmıştır. Dolayısıyla küresel finansal krizin dünya ekonomilerine etkilerinin, krizin uluslararası bulaşma ve yayılma kanalları çerçevesinde de incelenmesi önem arz etmektedir. $\mathrm{Bu}$ kapsamda değerlendirildiğinde dört önemli kanalın ön plana çıktığ1 görülmektedir. Kibritçioğlu (2011a, 2011b)’ye göre bu kanallar şunlardır:

1) Aşırı-riskli varlık ticareti kanalı (birinci finans kanalı): Kriz öncesinde ABD'de "zehirli" (toxic) niteliğine dönüşme riski taşıyan varlıkları edinmiş olan uluslararası finansal aktörlerin varlığı, ABD krizinin ilgili ülke ekonomilerine bulaşmasına sebep olmuştur.

2) Kredi kanalı (ikinci finans kanalı): Kriz nedeniyle daralan uluslararası kredi kanalları ve azalan ekonomik aktiviteler ilgili ülkelere olan fon akışlarını azaltmış ve bu yüzden krizin o ülkelere bulaşmasına aracı olmuştur.

3) Ticaret kanalı: ABD’nin dünya üzerindeki büyük ticaret gücünün zayıflamasına ek olarak, ABD ile yakın ticari ilişki içerisinde olan ülkelerde başlayan durgunluk ve reel gelir kayıpları sonucunda dış talepte daralmalar yaşanmış ve kriz o ülkelere de bulaşmıştır.

4) Beklentiler kanalı: Bu kanal ise tüketicilerin ve yatırımcıların oluşan olumsuz hava nedeniyle iyimserliklerini kaybetmesi ve belirsizliklerin artması ile birlikte güvenlerindeki azalma şeklinde ortaya çıkmıştır.

Krizin en fazla etkilediği ülke gruplarının başında Avrupa Birliği yer almaktadır. Avrupa, kriz döneminde en fazla daralan bölge olmakla kalmamış, krizden çıkış sürecinde en yavaş davranış sergileyen bölge olma özelliği de taşımıştır. Eurostat verilerine göre, AB(27)'nin büyüme oranı 2007'de \%3,2 iken, 2009 yılında \%-4,3'e düşmüş, 2010 yılında dünyanın reel GSYH'si \%4,9 büyürken, bu oran AB için \%1,9 olarak gerçekleşmiştir. Ayrica enflasyon oran1 2008 krizine kadar yatay bir seyir izlerken kriz ile birlikte aniden bir sıçrama yaparak \%3,7'ye yükselmiştir. Ancak hemen ertesi dönemde \%1'e kadar düşen enflasyon oranı 2010 yılında kriz öncesi seviyesine $(\% 2,1)$ geri dönmüştür. 2008 yılında Avrupa Birliği'nde hâkim olan stagflasyon korkuları yerini 2009 yılında deflasyon endişelerine bırakmıştır. Küresel kriz öncesi dönemde dünya ortalamasının altında seyreden AB işsizlik oranları, 2008 yılında \%7,1'den 2009 yılında \%9'a yükselmiş ve 2010 yılında ise $(\% 9,7)$ zirveye ulaşmıştır. Söz konusu dönemde bir başka makroekonomik istikrarsızlık, kamu maliyesi alanında kendini hissettirmiştir, AB(27) genelinde kamu açığının GSYH'ye oranı 2007 yılında \%0,9 iken 2009 yılında \%6,9 ve 2010 yilında \%6,6 olarak gerçekleşmiştir. Ayrıca, küresel kriz döneminde \%60'lar düzeyinde olan kamu borç stokunun GSYH'ye oranı 2008 yılında \%62,5, 2009 yılında \%74,7 ve 2010 yılında \%80,1 olarak gerçekleşmiştir.

Tam üyelik sürecinde olan Türkiye için AB, bir numaralı ticaret ortağı ve en önemli ihracat pazarıdır. TUİK verilerine göre 2008-11 döneminde Türkiye'ye gelen doğrudan yabancı yatırımların yaklaşık dörtte üçü ve Türkiye'nin toplam ticaretinin ortalama \%41,6's1 AB kaynaklıdır. Pazar çeşitliliğini artırmak için yoğun çaba göstermesine rağmen 
Türkiye'nin AB'deki yavaşlama ve durgunluk sonucu uğrayacağı pazar kayıplarını üçüncü ülkelerle ikame edebilmesi ise orta vadede oldukça zor görünmektedir.

Çalışmanın temel amacı, küresel krizin etkisiyle ortaya çıkan Avrupa borç krizinin yukarıda belirtilen finans, dış ticaret ve beklentiler kanalları çerçevesinde Türkiye ekonomisi üzerindeki etkilerini incelemektir. Bu amaca yönelik olarak çalışmanın ikinci bölümünde literatürde yer alan çalışmalara ve bunların bulgularına yer verilmektedir. Üçüncü bölümde Avrupa borç krizinin nedenleri, gelişimi ve Türkiye ekonomisini etkileme kanalları incelenmektedir. Dördüncü bölümde ise krizin söz konusu etki kanallarının ekonometrik analizi yapılmaktadır. Bunun için öncelikle borç krizi göstergesi olarak kullanılacak olan "finansal kırılganlık endeksinin" hesaplanma süreci ve bu endeksi oluşturan değişkenler açıklanmaktadır. Daha sonra da ARDL (Sınır Testi) yöntemi kullanılarak, 2004:Q12014:Q3 dönemi için finansal kırılganlık endeksi (FVE) ile borç krizinin Türkiye ekonomisine yayılma kanallarını temsil eden uluslararası yatırım pozisyonu açığı (IIP), toplam dış ticaret hacmi (TV), tüketici güven endeksi (CCI) ve reel kesim güven endeksi (RCI) değiş̧kenleri arasındaki ilişki analiz edilmektedir. Çalışmanın sonuç bölümünde elde edilen bulgular değerlendirilmektedir.

\section{Literatür}

Yaklaşık 25 yıldan beri krizlerin uluslararası yayılım mekanizmalarını açıklamak amacıyla teorik ve ampirik pek çok çalışma yapılmıştır. Asya krizinden önce yapılan çalışmalarda diş ticaret ve doğrudan yabancı yatırımlar (gelir etkisi) gibi direkt ilişkilere odaklanılmakla beraber, daha sonraki çalışmalarda krizlerin uluslararası yayılımı finansal kanallar yoluyla açıklanmaya başlanmıştır. Bu çalışmalara öncülük eden Krugman (1996) finansal şokların, hükümetlerin genişletici maliye politikası uygularken sabit kur sisteminde gerçekleşen spekülatif ataklardan oluşabileceğini ifade etmektedir. Asya krizinden sonra yapılan çalışmaların bazılarında "uyandırma alarmı"ndan da söz edilmektedir. Bu, bir ülkede ortaya çıkan finansal bir çalkantının küresel yatırımcıları harekete geçireceğini ve bu yatırımcıların diğer ülkelerin finansal ve makroekonomik koşullarını araştırmaya başlayarak ülkeden çıkış yapacağını ifade etmektedir. Bu tür bir yayılma çoğunlukla ekonomik temellerden değil, Masson (1998)'in belirttiği üzere tamamen davranışsal nedenlerden kaynaklanmaktadır. Dolayısıyla da yatırımcıların tercihlerindeki değişmelerin kaynaklarının belirlenmesi mümkün olamamaktadır.

Gros ve Mayer (2010), diş finansmanda meydana gelebilecek ani bir kesintiye karşı Euro bölgesi ülkelerinin (Portekiz, İrlanda, İtalya, Yunanistan, İspanya, Fransa, Belçika, Hollanda, Finlandiya, Avusturya ve Almanya) finansal kırılganlıklarını ölçmek üzere finansal kırılganlık endeksi oluşturmuşlardır. Bu endekste ülkelerin kamu maliyelerinin durumuna ilişkin olarak borç stoku ve bütçe dengesinin Gayrı Safi Yurtiçi Hâsıla (GSYH)'ya oranı, ulusal kaynakların varlığına ilişkin olarak tasarruf oranı, dış borcu servis etme gücüne ilişkin olarak ise cari denge/GSYH oranı ve birim işgücü maliyeti değişkenleri 
kullanılmıştır. Yunanistan, bu ülkeler arasında en yüksek kırılganlık endeksine sahip olan ülke konumunda iken, bölgenin diğer kırılgan ülkeleri arasında sırasıyla, Portekiz, İrlanda, İtalya, Yunanistan ve İspanya (PIIGS ülkeleri) yer almıştır.

IMF (2010)'in yaptı̆̆ bir çalışmada, küresel krizin gelişen piyasa ekonomileri üzerindeki etkileri ve krizin bu ekonomileri hangi kanallardan etkilediği incelenmiştir. Çalışmada dış âlem, kamu sektörü, finans sektörü ve özel sektör olmak üzere dört ayrı sektör ele alınarak her bir sektör için ayrı ayrı kırılganlık endeksi oluşturulmuştur. Her bir sektör için oluşturulan bu endeksler ağırlıklandırılmak suretiyle ekonominin geneline dair tek bir kırılganlık endeksi elde edilmiştir. Çalışmadan elde edilen bulgular doğrultusunda, kriz öncesi dönemde kırılganlıkları azaltan ve ekonominin temel göstergelerini iyileştiren yapısal reformların önemi vurgulanmıştır.

Çınar vd. (2010), 2007 yılının ikinci yarısında başlayan küresel kriz boyunca ülkelerin dış ticaret, sermaye akımları ve beklentiler kanallarıyla krizden nasıl etkilendiklerini, bu etkilenmenin derecesini ve ülkeler arasında nasıl farklılık gösterdiğini incelemişlerdir. Çalışmadan elde edilen bulgulardan ilki, ihracatın ekonomi içindeki payı yüksek olan, ağırlıklı olarak gelişmiş ülkelere ihracat yapan, küresel ekonominin devresel hareketlerine duyarlı ürünler ihraç eden ve yurt içi tasarruf imkânları düşük olan ülkelerin küresel krizden daha olumsuz etkilendikleridir. İkincisi, Türkiye'ye ilişkin bulgulardır. Buna göre, Türkiye ekonomisinin küresel krizin etkisini her üç kanal üzerinden de hissettiği, özellikle Türkiye'nin ihracat pazarlarının ve ihraç ürünlerinin özellikleri, ekonominin yurt dışı tasarruflara bağımlı yapısı ve özel sektörün ekonomiye ilişkin beklentilerinde ortaya çıkan bozulmalar nedeniyle krizin etkilerinin diğer ülkelere kıyasla daha belirgin olduğu sonucuna varılmıştır.

Kaya, Barlas ve Kalafatçılar (2011), Avrupa borç krizi sürecinde Euro bölgesi çevre ülkelerinde oluşan kırılganlıkları analiz etmiş ve yayılma kanallarından biri olarak ön plana çıkan bankacılık sektöründeki karşılıklı duyarlılıkları ortaya koymuştur. Çalışmada, borç krizinin en kuvvetli hissedildiği Euro bölgesi çevre ülkeleri için (Yunanistan, İrlanda, Portekiz, İspanya İtalya ve Belçika) kırılganlık endeksi oluşturulmuştur. Borç krizi sürecinde ön plana çıkan sorunlu sektörler ele alınmaya çalışılmış ve endeksin oluşturulmasında kamu sektörünü, bankacılık sektörünü, dış âlemi ve yapısal unsurları temsil eden değişkenler kullanılmıştır. Kriz sürecinde ortaya çıkan yapısal sorunları temsil etmek üzere işsizlik ve birim işgücü maliyetleri, bozulan kamu maliyesi göstergeleri olarak borç stoku/GSYH ve bütçe dengesi/GSYH oranları, bankacılık sektörü kırılganlıklarını tespit etmek amacıyla bankacılık sektörü kredi temerrüt swapları (CDS) ve Avrupa Merkez Bankası'ndan (ECB) borçlanma miktarları, ülkelerin dış finansman ihtiyaçlarını tespit etmek amaciyla da cari denge/GSYH ve uluslararası yatırım pozisyonu/GSYH oranları gibi değişkenler kullanılmıştır. 
Küçüksaraç, Özlü ve Ünalmış (2012a ve 2012b), kriz dönemlerinde Türkiye'nin ortak şoklara göreli tepkisinin farklılaşıp farklılaşmadığını (değişim bulaşıcılığı) incelemek amaciyla, 2002:01-2011:10 dönemi için Türkiye ve diğer gelişmekte olan ülkelerin ve ülke gruplarının haftalık hisse senedi, döviz kuru getirileri ve EMBI farklarını çalışmalarında veri seti olarak kullanmışlardır. Çalışmanın bulgularına göre, son dönemde yaşanan krizlerde Türkiye'nin diğer gelişmekte olan ülkelerden ayrışmadığı ve ortak şoklardan diğer ülkeler ile benzer şekilde etkilendiği sonucuna varılmıştır. Bu sonucun çalışmada yer alan tüm gelişmekte olan ülke grupları ve tüm piyasalar (döviz kuru, sermaye ve tahvil piyasaları) için geçerli olduğu vurgulanmıştır. Buna karşın, finansal piyasalarda beklenen getirilerin normal dönemlere kıyasla kriz dönemlerinde farklılaştığı ve gelişmekte olan ülkelere yönelen sermaye akımlarının kriz dönemlerinde tersine döndüğ̈̈ ortaya konmuştur. Özellikle, Avrupa ülkelerinin karşı karşıya olduğu borç sorunları nedeniyle, gelişmekte olan Avrupa ülkelerinde kriz dönemlerinin diğer gelişmekte olan ülkelere göre daha uzun süreli olduğu çalışmanın önemli sonuçlarından biridir.

Kibritçioğlu (2011c)'ye göre, Euro bölgesi ülkelerinde (özellikle PIIGS ülkelerinde kendini daha fazla hissettiren) kamusal borç krizi, küresel ekonomik krizin temel bileşenlerinden biridir ${ }^{1}$. Çalışmada PIIGS ülkelerinde çok yüksek olan kamu borç stoku düzeyine, yüksek bütçe açıklarına ve düşük ekonomik büyümeye dikkat çekilmektedir. Ayrıca bu ülkelerin çoğunda borçların vade ve para birimi yapısında, alacaklıların yerliyabancı dağılımında ve sözleşmelerin faiz yapısında da olumsuzluklar söz konusu olduğundan bu ülkelerdeki finansal kırılganlığın 2008-11 döneminde hızla arttığı vurgulanmaktadır. Borç krizinin çözümüne yönelik olarak AB'nin uygulayabileceği olası politika seçenekleri de ortaya konmuştur. Borç krizinden çıkılması ve/veya krizin diğer Avro Bölgesi ülkelerine yayılmasının önlenmesinin de ancak AB'nin (özellikle Almanya ve Fransa) alacağı bazı kısa ve uzun vadeli kapsamlı politik kararlarla mümkün olabileceği ileri sürülmektedir.

Çiftçi ve Çeviş (2012), 2008 finansal krizinin Avrupa Birliği'nin kamu borcuna etkisini ve Avrupa borç krizi ile kredi temerrüt swapları ilişkisini analiz etmişlerdir. Bu çalışmada 2004:Q1-2011:Q2 döneminde Avrupa Birliği üyesi 14 ülkenin (Yunanistan, Macaristan, İtalya, Belçika, Portekiz, Romanya, İspanya, Polonya, Slovakya, Fransa, Danimarka, Almanya, Finlandiya ve İsveç) kredi temerrüt swapları ile Kamu Borcu/GSYH ilişkisi panel veri analizi ile incelenmiştir. Ayrıca 2008 finansal krizinin etkisini görmek amacıyla bir "finansal kriz indeksi" hesaplanmış ve açıklayıcı değişken olarak modele dâhil edilmiştir. Sabit etki modelinin tahmin sonuçlarına göre her iki değişken ile kredi temerrüt swapları arasında beklenildiği gibi istatistiksel olarak anlamlı ve pozitif yönlü bir ilişkinin

1 Kibritçioğlu (2012a ve 2011b) 'de belirtildiği gibi küresel kriz, finans, dıs ticaret ve beklentiler kanalları diğer ülke ekonomilerine yayılmıştır. 
olduğu tespit edilmiştir. Kamu Borcu/GSYH oranındaki bir birimlik artış CDS oranlarını 11,9 birim artırırken, finansal kriz indeksindeki bir birimlik artış ise CDS oranlarını 5,6 birim artırmaktadır. Çalışmada Avrupa'nın talebi daraltıcı politikalar yerine, büyümeye odaklı ve para politikasıyla uyumlu bir maliye politikası uygulaması ve kalıcı bir kurtarma fonu ile mali canlandırmayı gerçekleştirmesi gerektiği önerilmiştir.

Erer ve Erer (2012), Euro bölgesi borç krizinin Türkiye ve gelişmekte olan ülkeler üzerindeki etkilerini incelemişlerdir. Çalışmada, 1990-2011 dönemi için panel veri analizi yöntemi kullanılarak Türkiye, Arjantin, Brezilya, Bulgaristan, Şili, Çin, Rusya, Malezya, Tayland, Meksika, Kolombiya, Makedonya, Romanya, Hindistan, Endonezya, Moldova, Filipinler, Ukrayna, Letonya ve Litvanya ülkelerine ait ekonomik büyüme oranı, özel tüketim harcamaları, kamu tüketimi ve dışa açıklık değişkenleri ile PIIGS (Portekiz, İtalya, İrlanda, Yunanistan ve İspanya) ülkelerinin 1990-2011 dönemindeki genel kamu dengesi değişkeninin ortalaması alınarak oluşturulan PIIGS değişkeni arasındaki ilişki araştırılmıştır. Ayrıca, borç krizinin etkisini görmek amacıyla da kriz kukla değişkeni kullanılmıştır. Çalışmadan elde edilen bulgulara göre, Euro bölgesi borç krizinin ve kriz döneminde PIIGS ülkelerinin genel kamu dengesinin ve dişa açıklığın gelişmekte olan ülkelerin ekonomik büyümelerini olumsuz yönde etkilediği sonucuna varılmıştır.

Doğru (2012), küresel kriz sürecinde ABD'de ve AB Bölgesi’nde meydana gelecek üretim kayıplarının Türkiye ekonomisi üzerindeki etkilerini, krizin etkileme kanallarını (beklentilerde kötümserlik, ihracatta azalma ve finansal sermaye girişlerinde azalma) kapsayan cari işlemler hesabı modeli üzerinden analiz etmiştir. 1995:Q1 - 2011:Q2 dönemi için EKK yöntemi ve eş-bütünleşme yöntemlerinin kullanıldığı bu çalışmada, Türkiye'nin ticaret ortakları olan Amerika ve AB bölgesindeki üretim düşüşünün Türkiye'nin cari açığı ile kısa dönemde anlamlı bir ilişkisinin olmadığı, ancak uzun dönemde bu ticaret ortakları potansiyel büyümeden daha az büyüdüklerinde Türkiye ekonomisinin daha fazla cari açık verdiği sonucuna varılmıştır.

Rengasamy (2012), Euro bölgesindeki gelişmelerin ve borç krizi ilgili güncel politika duyurularının, BRICS ülkeleri (Brazilya, Rusya, Hindistan, Çin, Güney Afrika) hisse senedi borsalarının ortalama getirileri ve oynaklık yapısı üzerindeki etkisini analiz etmiştir. Çalışmada veriler, Temmuz 2009-Nisan 2010 arası dönem (Eylül 2008 küresel krizi sonrası dünya finansal piyasaların iyileşme göstermeye başladığı ve henüz Yunanistan hariç, Euro bölgesi için paniğin olmadığı 10 aylık dönem) ve Mayıs 2010- Şubat 2012 arası dönem (finansal piyasaların türbülansa girdiği, EFSF'nin (the European Financial Stability Facility) oluşturulduğu ve 750 Milyar €'luk kurtarma paketinin açıklandığı, PIIGS ülkelerinin kırılganlıklarının gözler önüne serildiği 22 aylık dönem) olmak üzere iki dönemi kapsayacak şekilde istatistiksel olarak incelenmiştir. Çalışmanın bulgularına göre, otuz iki aylık dönem içerisinde ortalamadan en yüksek getiri sağlayan borsaların Rusya $(\% 1,07)$, Hindistan $(\% 0,66)$ ve Güney Afrika $(\% 0,61)$ 'nın olduğu ve hiçbir BRICS borsasında bu dönemde negatif getirinin ortaya çıkmadığı, oynaklığın en düşük olduğu ülkeler arasında yer alan 
Brezilya $(\% 5,72)$ ve Hindistan $(\% 5,95)$ borsalarının küresel yatırımcılar için firsat oluşturduğu, bunun aksine borç krizi döneminde ise tüm BRICS ülke borsalarında getirilerin düştüğü (Brezilya, Hindistan ve Çin borsalarında negatif getiri), oynaklıkların arttığı sonucuna ulaşılmıştır.

Aysan ve Ermişoğlu (2013,) Euro borç krizinin nedenlerini, krizin ortaya çıkış sürecini, krize karşı alınan önlemleri ve son olarak da borç krizinin Türkiye'yi etkileme kanallarını analiz etmişlerdir. Çalışmada Euro borç krizinin nedenleri, parasal birlikte ortaya çıkan yapısal sorunlar, parasal birlikteki makroekonomik istikrarsılıklar ve bölgedeki finansal sistemde ortaya çıkan sorunlar olmak üzere üç başlık altında ele alınmıştır. Ayrıca borç krizinden Türkiye'nin özellikle ticaret kanalı, finans kanalı ve beklentiler kanalı olmak üzere üç kanaldan etkilendiği vurgulanmıştır. Türkiye'nin güçlü makroekonomik ve finansal yapısı nedeniyle krizin Türkiye ekonomisi üzerindeki etkilerinin sınırlı kaldığı ileri sürülmüştür.

Lee vd. (2013) ise, Avrupa Birliği'nin Asya ihracatının önemli bir payına sahip olması ve bölgedeki doğrudan sermaye ile diğer sermaye akımlarının önemli bir kaynağını oluşturması nedeniyle küresel krizin etkileri kadar olmasa da borç krizinin ticaret ve finans kanalı ile Asya ekonomilerini etkilediğini belirtmektedir. Çalışmada, bu etkinin ne kadar olduğunu ortaya koyabilmek amaciyla regresyon analizi ve VAR analizi yöntemleri kullanılarak bu kanallar ayrı ayrı incelenmiştir. Ticaret kanalının yanı sıra, özellikle bankacılık sektörü üzerinden finans kanalının daha etkin işlediği sonucuna varılmıştır.

Stracca (2013), 2010-2013 döneminde Euro bölgesinde ortaya çıkan önemli siyasi olaylar ve kararlar çerçevesinde kriz olguları tespit etmiş ve bu kriz olgularının küresel finansal piyasalarda ortaya çıkardığı etkileri analiz etmiştir. Bu amaçla, Euro bölgesinde bu dönemde tespit edilen kriz olguları ile Ocak 2010-Mayıs 2013 dönemine ait 25 gelişen piyasa ekonomilerinin 10-yıl vadeli devlet tahvilinin getirisi, hisse senedi getirisi ve döviz kuru değişkenleri arasındaki ilişki günlük veriler ile panel veri analizi yöntemi kullanılarak incelenmiştir. Çalışmadan elde edilen bulgular doğrultusunda, ticaret ve finans alanlarında Euro alanı ile bağlantılı olan tüm gelişen piyasa ekonomileri, özellikle yüksek getirinin olduğu ülkeler arasında tüm varlıklar için (döviz kuru hariç) istatistiksel olarak anlamlı ilişki elde edilmiş ve finansal entegrasyon kanalının krizin gelişen piyasa ekonomilerine bulaşmasında en önemli kanal olduğu sonucuna varılmıştır.

Neri ve Ripele (2015), Euro borç krizinin tüm bölge ekonomileri üzerindeki makroekonomik etkileri ve Avrupa Merkez Bankası'nın uyguladığı gevşek para politikasının krizin olumsuz etkilerini ortadan kaldırma konusundaki etkinliğini, Faktör Genişletilmiş Vektör Oto-Regresif (FAVAR) modeli kullanarak Aralık 2012-Ocak 2007 dönemi için analiz etmişlerdir. Veri setinde faiz oranı, kredi hacmi, sanayi üretim endeksi, işsizlik oranı, enflasyon oranı, Euro bölgesi ticaret hacmi, hane halkı ve firmaların güven endeksi ve Euro bölgesi diğer finansal ve reel değişkenleri yer almaktadır. Çalışmadan elde 
edilen bulgulara göre 2009 yılının sonlarına doğru Yunanistan'da başlayan borç krizinin bankacılık kanalı, güven kanalı ve ticaret kanalı ile hızlı bir şekilde diğer ülke ekonomilerine özellikle zayıf finansal ve makroekonomik koşullara sahip olanlara (Portekiz, İrlanda, İspanya ve İtalya gibi) doğrudan biçimde yayılma gösterdiği sonucuna varılmıştır. Ayrıca, Avrupa Merkez Bankası'nın uyguladığı gevşek para politikasının krizin olumsuz etkilerini hafifletmede katkı sağladığı çalışmanın önemli sonuçlarından biridir.

\section{Avrupa Borç Krizinin Nedenleri, Gelişimi ve Türkiye Ekonomisini Etkileme Kanalları}

AB'yi borç krizine sürükleyen etkenlerin başında elbette ki küresel finansal kriz gelmektedir. AB de diğer dünya ülkeleri ve ABD gibi küresel finansal krizden çıkış için bazı politikalar devreye sokmuştur. "Likidite sıkışıklığı" yaşanan bu dönemde merkez bankalarının uyguladığı genişletici para politikaları ile piyasalara para enjekte edilmiştir. Avrupa Merkez Bankası'nın fiyat istikrarını sağlamak adına enflasyonu \%2 sınırında tutma hedefi, para politikasının ABD’deki kadar genişletici olmasının önüne geçmiştir. Zor durumda kalan ve batmak üzere olan bankalara yönelik kurtarma operasyonları gerçekleştirilirken diğer taraftan da genişletici maliye politikaları ile piyasalardaki para kuraklığına son verilmek istenmiştir. Fakat bütün bunlar kamu maliyesinin üzerinde ağır yükler oluşturmuştur. Artan kamu harcamaları ve azalan gelirler bütçe açıklarını ciddi oranlarda artırmıştır. Artan bütçe açıkları ise kamu borçlanmalarını arttırmış ve kısaca birbirine bağlı işleyen mekanizma borç krizini tetiklemiştir.

Yaşanan küresel gelişmelerin yanı sıra Euro bölgesinin yapısal sorunları Avrupa'yı borç krizi sarmalına sürükleyen temel unsur olmuştur. Kutlay (2011)'e göre bu yapısal sorunları, Euro bölgesinde para ve maliye politikalarının uyuşmazlığı ve finansal sistemin mimarisinden kaynaklanan zafiyetler olmak üzere iki başlık altında toplamak mümkündür. 1999 yılında Ekonomik ve Parasal Birlik ile Euro Bölgesi için ortak para politikası uygulanırken, maliye politikasının üye ülkelerin ulusal karar alıcılarının inisiyatifinde bulunması iki politikanın da sürdürülebilir olmasında büyük çıkmazlara yol açmıştır. Bu uyumsuzluğu gidermek adına bazı önlemler ${ }^{2}$ alınsa da üye ülkelerin birbiriyle farklılıklar göstermeleri nedeniyle bu yapısal sorun aşılamamıştır. Euro Bölgesi'ne has nitelikte olmayan finans sisteminin denetimden uzak olması, borç krizinin temelini oluşturan diğer

2 Para ve maliye politikası uyumunu sağlamak adına geliştirilen tedbirler; Istikrar ve Büyüme Paktı ile mali disiplin sağlanmaya çalışılmış, Avrupa Merkez Bankası'nın bă̆ımsızlı̆̆ Maastricht Anlaşması ile güvence altına alınmış ve üye ülke devletlerinin sorumsuzca borçlanmasını önlemek ve diğer üye ülkelere güvenerek borçlanmanın önüne geçmek adına Mali Transfer Yapmama Prensibini benimsemiştir. Ancak uygulamaya konulan bu kurallar işe yaramamış, bölge içerisinde konulan bu tedbirlerden mali disiplini sağlamaya yönelik olan Istikrar ve Büyüme Paktı çerçevesinde bütçe açıklarl ve borçlanma oranlart ile ilgili olan kural birçok üye ülke tarafindan ihlal edilmiştir. 
bir yapısal sorunudur. Globalleşen finans piyasalarının yeterince denetlenmeyen, düzenlenmeyen ve şeffaflıktan uzak bir şekilde işlemesi, riskli finansal varlıkların gün yüzüne çıkmasına neden olmuş ve yüksek risk-yüksek kar mantığında aşırı risk birikimine göz yuman Birlik ülkelerinin borçluluk oranlarının artması kaçınılmaz olmuştur.

Birlik içindeki bu yapısal sorunların kronik yapısı nedeniyle artan kırılganlıklar, ortaya çıkan zor koşullarda direnme gücünü zayıflatmış ve ekonomik açıdan birbirlerine bağlı olan üye ülkelerden birinde meydana gelen bir hastalığın diğerine hemen bulaşmasına davetiye çıkarmıştır. İlk olarak Yunanistan'da patlak veren borç krizinin, adeta domino etkisi ile sorunlu olan diğer üye ülkelere (Portekiz, İspanya, İrlanda ve İtalya gibi) kısa zamanda yayılması gerçekleşmiştir. Tablo 1 ve 2'de bu ülkelere ait kamu bütçe açıkları oranları ve kamu borç stoku oranları verilmiştir.

\section{Tablo: 1}

Kamu Bütçe Açı̆̆ı /GSYH Oranı (\%)

\begin{tabular}{|c|c|c|c|c|c|}
\hline & İranda & Yunanistan & Íspanya & İtalya & Portekiz \\
\hline $\mathbf{2 0 0 9}$ & $-13,9$ & $-11,5$ & $-11,0$ & $-5,3$ & $-9,8$ \\
\hline $\mathbf{2 0 1 0}$ & $-32,5$ & $-17,6$ & $-9,4$ & $-4,2$ & $-11,2$ \\
\hline $\mathbf{2 0 1 1}$ & $-12,7$ & $-10,2$ & $-9,4$ & $-3,5$ & $-7,4$ \\
\hline $\mathbf{2 0 1 2}$ & $-8,1$ & $-8,7$ & $-10,3$ & $-3,0$ & $-5,6$ \\
\hline $\mathbf{2 0 1 3}$ & $-5,8$ & $-12,3$ & $-6,8$ & $-2,9$ & $-4,8$ \\
\hline $\mathbf{2 0 1 4}$ & $-4,1$ & $-3,5$ & $-5,8$ & $-3,0$ & $-4,5$ \\
\hline
\end{tabular}

Kaynak: Eurostat.

Tablo: 2

Kamu Borç Stoku/GSYH Oranı (\%)

\begin{tabular}{|c|c|c|c|c|c|}
\hline & İrlanda & Yunanistan & İspanya & İtalya & Portekiz \\
\hline $\mathbf{2 0 0 9}$ & 62,3 & 105,8 & 52,7 & 112,5 & 83,6 \\
\hline $\mathbf{2 0 1 0}$ & 87,4 & 110,7 & 60,1 & 115,3 & 96,2 \\
\hline $\mathbf{2 0 1 1}$ & 111,2 & 171,3 & 69,2 & 116,4 & 111,1 \\
\hline $\mathbf{2 0 1 2}$ & 121,7 & 156,9 & 84,4 & 123,1 & 125,8 \\
\hline $\mathbf{2 0 1 3}$ & 123,2 & 175,0 & 92,1 & 128,5 & 129,7 \\
\hline $\mathbf{2 0 1 4}$ & 109,7 & 177,1 & 97,7 & 132,1 & 130,2 \\
\hline
\end{tabular}

Kaynak: Eurostat.

Euro Bölgesinde ortaya çıkan borç krizinin birlik ülkeleri ile entegre olan diğer ülke ekonomileri gibi Türkiye ekonomisini de üç kanaldan etkilemesi beklenebilir. Şekil 1'den de görülebileceği gibi bu etki kanallarından ilki, bankacılık ve finans sistemlerinin globalleşmenin etkisiyle birbirlerine daha da güçlü entegre olmasından kaynaklı sermaye hareketlerinden doğacak aşağı yönlü risklerin oluştuğu sermaye ve finans kanalıdır. İkinci etki kanalı, mal ve hizmet ticareti akımları yoluyla dış talepte meydana gelen düşüşlerin oluştuğu dış ticaret kanalıdır. Son etki kanalı olarak ise, küresel ortamda var olan olumsuz koşullardan ötürü ekonomiye duyulan güvendeki azalmanın oluşturduğu beklentiler kanalıdır.

Ekonomide tüketici ve firma davranışları, ekonominin büyüme potansiyeli ve politika yapıcıların alacağı kararlar açısından oldukça önemli bir yere sahiptir. TCMB (2012a ve 2012b)'ye göre Tüketici Eğilim Anketi ile tüketicilerin genel ekonomik duruma, iş bulma olanaklarına, piyasalardaki gelişmelere ve kişisel mali durumlarına ilişkin 
eğilimlerinin ve beklentilerinin öğrenilmesi, yakın gelecekte yapılması planlanan harcamalara ilişkin aylık tüketici eğilimlerinin saptanması amacıyla ekonominin öncü göstergelerinden biri olan tüketici güven endeksi oluşturulmaktadır. Tüketici güvenindeki iyimserlik, harcama yapma isteğini ve borca girme eğilimini artırabilirken, kötümserlik ise tüketici davranışlarında tersine etkiler yaratabilmektedir. Benzer şekilde, diğer öncü göstergelerden biri de reel kesim güven endeksidir. Bu endeks üreticilerin yatırım yapma isteğinin ve risk alma eğilimlerinin göstergesi olarak kullanılmaktadır. Üretici güvenindeki iyimserlik yatırım yapma isteğini ve riske girme eğilimini yükseltebilmekte, kötümserlik ise tersine etkilere neden olabilmektedir.

Şekil: 1

Avrupa Borç Krizinin Türkiye'yi Etkileme Kanalları

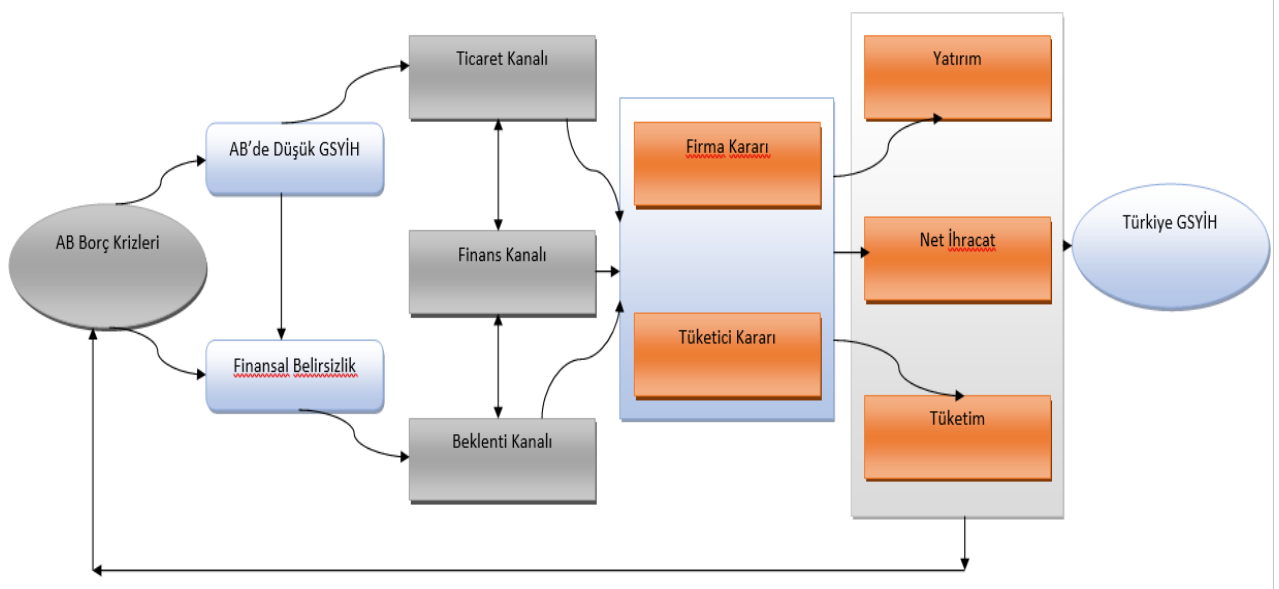

Kaynak: Yazarlar tarafindan hazırlanmıştır.

TCMB verilerine göre, 2004-2014 arası dönemde yurtdışından Türkiye'ye gelen doğrudan yabancı yatırımların coğrafik dağılımı incelendiğginde toplam doğrudan yatırımların yaklaşı \%80'inin $\mathrm{AB}$ ülkelerinden geldiği görülmektedir. 2008 öncesi ve sonrasında bu oranda önemli değişiklikler söz konusu değildir.

Türkiye'nin toplam ihracatının ve ithalatının coğrafik dağılımına bakıldığında ise Türkiye'nin toplam ihracatında gelişmiş ülkeler, özellikle Avrupa Birliği ülkeleri önemli bir paya sahiptir. TUIK verilerine göre, 2008 yılı öncesi toplam ihracatın yaklaşı $\% 55^{\prime} \mathrm{i} A B$ ülkelerine gerçekleştirilirken 2008 yılı sonrası bu oran $\% 45$ 'lere düşmüştür. Buna karşın 2010 yılı sonrası Yakın ve Orta Doğu ülkelerinin payı 2008 öncesinde \%14'iken 2008 sonrası dönemlerde \%20'lere ulaşarak belirgin bir artış göstermiştir. Benzer şekilde, AB'den gerçekleştirilen ithalatın toplam ithalat içerisindeki payının, 2008 öncesi yaklaşık \%45 iken 
2008 yılı sonrasında \%35'lere gerilediği görülmektedir. Buna karşın, 2009 yılı sonrası Yakın ve Ortadoğu Ülkeleri'nin ve diğer Asya Ülkeleri'nin pay1 \%5'lerden \%9'lara yükselmiştir.

İktisadi karar birimlerinin (tüketici ve firmaların) beklentileri, özellikle kriz dönemlerinde, tüketim ve yatırım talebinin istikrarlı bir seyir izlemesi ve para-kredi piyasalarının etkin bir şekilde işleyişi açısından önem taşımaktadır. 2004-2014 döneminde Türkiye'ye ait Tüketici Güven Endeksi ve Reel Kesim Güven Endekslerinin aldığı değerlere bakıldığında her iki endekste de 2008-2009 yıllarında önemli ölçüde düşüşler olduğu ve 2010 yılının başlarında ortalama değerlerine geri döndükleri görülmektedir. Tüketici güven endeksi 2008 öncesi dönemlerde 80 düzeyindeyken, 2008 ve 2009 y1llarında 65 düzeyindedir. Reel kesim güven endeksi ise 2008 öncesi dönemde 115 iken 2008 ve 2009 yıllarında sırasıyla 52 ve 98 değerlerine kadar gerilemiştir. Güven endekslerinin izlediği bu seyir, krizlerin Türkiye'de özel sektörün ekonomiye ilişkin beklentilerinde bir bozulma etkisi yarattığını, buna karşın alınan politika önlemlerinin ${ }^{3}$ beklentiler konusunda ne denli etkili olabildiğini ortaya koymaktadır.

\section{Borç Krizinin Türk Ekonomisine Etki Kanallarının Ekonometrik Analizi}

Çalışmanın bu bölümünde öncelikle, $\mathrm{AB}$ borç krizinin Türkiye ekonomisini hangi kanallardan etkilediğini ortaya koyabilmek için oluşturulacak ekonometrik modelde borç krizini temsil etmek üzere kullanılacak olan Euro bölgesi finansal kırılganlık endeksi hesaplanacaktır. Daha sonra kullanılan veri seti, değişkenler ve ekonometrik metodoloji açıklanacak ve çalışmadan elde edilen bulgulara yer verilecektir.

\subsection{Euro Bölgesi Finansal Kırılganlık Endeksi (FVE)}

Euro Bölgesi için "Finansal Kırılganlık Endeksi” oluşturulurken, 2008 küresel finansal kriz ve Avrupa borç krizi sürecinde öne çıkan problemli sektörler dikkate alınmıştır. Buna göre Euro Bölgesi Finansal Kırılganlık Endeksi’nin hesaplanmasında kamu sektörü değişkenleri olarak kamu borç stokunun GSYH'ye oranı ve kamu bütçe dengesinin GSYH'ye oranı; finans sektörü değiş̧kenleri olarak 10 yıllık kamu borçlanma faiz oranı; reel sektör değiş̧keni olarak GSYH'nin büyüme oranı, işsizlik oranı, birim işgücü maliyetindeki \%değişme ve işgücü verimliliğindeki \%değişme; dış finansman sektörü değişkenleri olarak ise cari işlemler dengesinin GSYH'ye oranı ve net uluslararası yatırım pozisyonun GSYH'ye oranı olmak üzere toplam 9 değişken kullanılmıştır (Tablo3). 
Tablo: 3

Euro Bölgesi Finansal Kırılganlık Endeksi Hesaplanmasında Kullanılan Değişkenler*

\begin{tabular}{|l|c|}
\hline Değişken Adı & Sembol \\
\hline Kamu borç stoku/GSYH & GDS \\
\hline Bütçe dengesi/GSYH & BD \\
\hline Cari işlemler dengesi/ GSYH & CB \\
\hline İktisadi büyüme oranı & GR \\
\hline Birim işgücü maliyetindeki yüzde değişme & LC \\
\hline İşücü verimliliğindeki yüzde değişme & LP \\
\hline İşizlik oranı & U \\
\hline 10 yıllık kamu borçlanma faiz oranları & INT \\
\hline Uluslararası yatırım pozisyonu/GSYH oranı & IIP \\
\hline
\end{tabular}

*Endeksin hesaplanmasinda kullanılan değişkenlere ait veriler Eurostat kaynaklıdır.

Tablo 3'de yer alan değişkenlerin 2004:Q1-2014:Q3 dönemindeki her bir gözlem değerinin standart sapmalarına bölünerek standartlaştırılmış değerleri elde edilmiş ve bu standartlaştırılan değerlerin kullanılması suretiyle değişkenler ağırlıklandırılmıştır.

$$
F V E_{t}=\frac{G D S_{t}}{\sigma_{G D S}}-\frac{B D_{t}}{\sigma_{B D}}-\frac{C B_{t}}{\sigma_{C B}}-\frac{G R_{t}}{\sigma_{G R}}+\frac{L C_{t}}{\sigma_{L C}}-\frac{L P_{t}}{\sigma_{L P}}+\frac{U_{t}}{\sigma_{U}}+\frac{I N T_{t}}{\sigma_{I N T}}-\frac{I I P_{t}}{\sigma_{I I P}}
$$

Kamu bütçe dengesindeki, cari işlemler dengesindeki, büyüme oranındaki, işgücü verimliliğindeki ve net uluslararası yatırım pozisyonu oranındaki iyileşmeler finansal kırılganlığı azaltacağından dolayı bu değişkenler (-) işaretli; buna karşın kamu borç stokundaki, birim işgücü maliyetlerindeki, işsizlik oranındaki ve kamu borçlanma faiz oranındaki bozulmalar finansal kırılganlığı artıracağından dolayı bu değişkenler (+) işaretli olarak endekse dâhil edilmişlerdir.

Şekil: 2

\section{Euro Bölgesi Finansal Kırılganlık Endeksi}

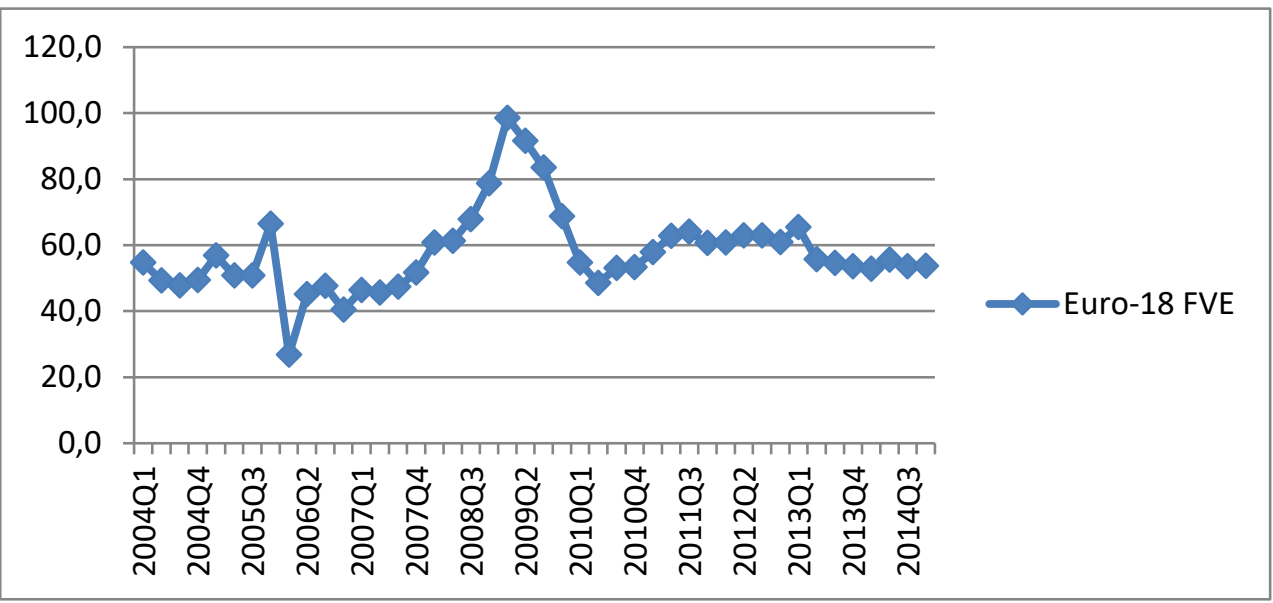


Şekil 2’ye göre Euro Bölgesi Finansal Kırılganlık Endeksi, 2008:Q3 döneminden itibaren yükselmeye başlamış ve özellikle 2009:Q1 döneminde en yüksek seviyesine ulaşmıştır. Bölgenin kırılganlık endeksinde bu dönemde ortaya çıkan yükselme, ABD kaynaklı olarak nitelenen 2008 küresel finansal krizinin yayılma kanalları ile Euro bölgesinin makroekonomik göstergeleri üzerindeki bozucu etkilerini göstermektedir.

Dünyadaki birçok ülke, küresel finansal krizden kurtulabilmek için 2009 yllından itibaren çeşitli önlemler almış ve bu önlemleri uygulamaya başlamıştır. Alınan önlemlerin olumlu etkileri sonucu krizin yıkıcı etkileri kısmen giderilmiştir. Bu kısmi toparlanma, dünya ülkelerinin küresel finansal krizden sonra uyguladıkları kurtarma operasyonları, geniş çaplı teşvik paketleri ve piyasalara aktarılan likiditeler sayesinde gerçekleşmiştir. Euro Bölgesinin bu süreçte hızlı bir toparlanma sürecine giremediği ve alınan önlemlerin krizden çıkışta yeterli olmadığı endeks değerinin ancak 2013:Q3 döneminde 2008:Q3 dönemi düzeyine ulaşmasından anlaşılmaktadır. Yapılan müdahaleler geçici toparlanmalar sağlamasına rağmen, bütçe açıklarının ve kamu borçlarının artma eğilimine girmesine neden olmuştur. Nitekim 2010 yılında Yunanistan'da patlak veren borç krizi ve diğer sorunlu Avrupa ülkelerinden bazılarının Yunanistan'ın ardından yardım çağrısında bulunmaları (özellikle zayıf finansal ve makroekonomik koşullara sahip olan Portekiz, İrlanda, İspanya ve İtalya gibi) 2010 yılının son çeyreğinden itibaren Euro Bölgesi için kırılganlık endeksinin tekrar yukarı yönde ivme kazanmasına yol açmıştır. 2011 yılında Euro Bölgesi ülke ekonomileri için kırılganlıkların artması, ekonomik faaliyetlerin yavaşlamasına ve makroekonomik göstergelerin aşağı yönlü gidiş riskinin tekrar artmasına neden olmuştur.

\subsection{Veri Seti ve Değişkenler}

$\mathrm{Bu}$ çalışmada kullanılan veri seti $\mathrm{AB}-18$ ülkeleri için önceki bölümde oluşturulmuş olan finansal kırılganlık endeksi (FVE) ile Türkiye'ye ait dış ticaret hacmi (TV), uluslararası yatırım pozisyonu açığı (IIP), tüketici güven endeksi (CCI) ve reel kesim güven endeksi (RCI) değerlerinden oluşmaktadır. 2004:Q1-2014:Q3 dönemine ait olan bu veriler EUROSTAT ve TCMB'den elde edilmiştir.

\subsection{Ekonometrik Metodoloji}

Makroekonomik göstergeler ile finansal göstergeler arasındaki kısa ve uzun dönem ilişkilerin incelenmesinde sıklıkla kullanılan yöntemlerden biri, Oto-Regresif Dağıtıcı Gecikmeli Model (ARDL)'dir. ARDL yöntemi Pesaran ve Shin (1998) tarafindan ortaya konmuş ve Pesaran vd. (2001) tarafindan geliştirilmiştir. Yaygın bir kullanım alanına sahip olan ARDL yöntemi, eş-bütünleşme ve kısa/uzun dönem ilişkilerin analizinde kullanılan diğer geleneksel ekonometrik yöntemlere göre bazı avantajlara sahiptir.

İlk olarak, Johansen (1991), Engle-Granger (1987) ve Vektör Oto Regresif (VAR) modellerinin aksine, ARDL yönteminde tüm değişkenlerin aynı düzeyde durağan olması gerekmemektedir. Değişkenler, düzeyde $I(0)$ ya da birinci farkta $I(1)$ durağan olsa bile 
ARDL yöntemi kullanılabilmektedir (Duasa, 2007; Adom vd. 2012). Bununla birlikte ARDL yöntemi, durağan olmayan ikinci dereceden I(2) bütünleşik seriler ile çalışmamaktadır. Finansal zaman serisi değişkenleri sıklıkla $I(0)$ veya $I(1)$ oldukları için ARDL yöntemini kullanmak önemli bir avantaj sunmaktadır. Çünkü ARDL yönteminde kullanılan değişkenlerin düzey değerleri ile çalışılabilmektedir. Oysa diğer yöntemlerde, değişkenlerin durağan hale geldikleri düzeyleri ile analiz yapılabildiği için değişkenler arasındaki uzun dönem ilişkilerin bilgi israfı nedeniyle kaybolabilmesi mümkündür. İkinci olarak, ARDL yöntemi uzun dönem bilgilerini kaybetmeden Hata Düzeltme (ECM) terimi kullanılarak tanımlanan uzun dönem dengesi ile verilen değişkenlerin kısa dönem etkilerini toplulaştırmaktadır. Dolayısıyla, eş-anlı olarak verilen değişkenler arasındaki kısa ve uzun dönem ilişkileri değerlendirilebilmektedir. Üçüncü olarak, geleneksel eş-bütünleşme yöntemlerinin aksine ARDL yönteminde, her bir değişken için farklı gecikmeler belirlenebilir. Bu farklılık ARDL yönteminin diğer geleneksel yöntemlere göre daha esnek olduğunu göstermektedir. Son olarak, eş-bütünleşme yöntemlerinin çoğu seçilen örneklemin büyüklüğüne çok duyarlıdır. Oysa ARDL yöntemi küçük örneklemlerde bile güvenilir sonuçlar vermektedir.

$\mathrm{Bu}$ çalışmada, Avrupa Birliği için hesaplanan finansal kırılganlık endeksinin Türkiye'nin incelemeye konu edilen makroekonomik göstergelerini ne yönde etkilediği sorusuna cevap aranmaktadır. Bu amaçla analizde tüketici güven endeksi, reel kesim güven endeksi, ticaret hacmi ve uluslararası yatırım pozisyonu kullanılmaktadır. Analizde kullanılan değişken tanımları aşağıdaki gibidir:

$R C I$ : Reel kesim güven endeksi;

$C C I$ : Tüketici güven endeksi;

$F V E$ : Finansal kırılganlık endeksi;

$T V$ : Ticaret hacmi;

IIP : Uluslararası yatırım pozisyonu;

$\Delta$ : Değişkenlerin birinci fark1;

Uygun ARDL modelleri ise aşağıdaki gibidir:

$$
\begin{gathered}
\Delta R C I_{t}=\alpha+\sum_{i=1}^{n} \beta_{i t} \Delta R C I_{i, t-i}+\sum_{i=0}^{p} \phi_{i t} \Delta F V E_{i, t-i}+\delta_{1 i} R C I_{t-i}+\delta_{2 i} F V E_{t-i}+\varepsilon_{i t} \\
\Delta C C I_{t}=a+\sum_{i=1}^{m} b_{i t} \Delta C C I_{i, t-i}+\sum_{i=0}^{q} c_{i t} \Delta F V E_{i, t-i}+d_{1 i} C C I_{t-i}+d_{2 t} F V E_{t-i}+v_{i t} \\
\Delta T V=e+\sum_{i=1}^{r} f_{i t} \Delta T V_{i, t-i}+\sum_{i=0}^{s} g_{i t} \Delta F V E_{i, t-i}+h_{1 i} T V_{t-i}+h_{2 i} F V E_{t-i}+\mu_{i t}
\end{gathered}
$$




$$
\Delta I I P=f+\sum_{i=1}^{r} g_{i t} \Delta I I P_{i, t-i}+\sum_{i=0}^{s} h_{i t} \Delta F V E_{i, t-i}+k_{1 i} I I P_{t-i}+k_{2 i} F V E_{t-i}+n_{i t}
$$

$\varepsilon_{i t}, v_{i t}, n_{i t}$, ve $\mu_{i t}$, ortalaması sıfir ve varyans1 sabit olan hata terimleri olup tüm veriler hem veri setindeki çarpıklığı azaltmak hem de örneklem ölçeğini küçültmek amacıyla logaritmik formda ele alınmıştır. Böylece tahmin edilen katsayıların esneklik şeklinde yorumlanması da sağlanmıştır.

(1), (2), (3) ve (4) numaralı denklemler tahmin edildikten sonra her bir denklem için sınır testi F-istatistiği ile yapılır. Modelde kullanılan değişkenler arasında eş-bütünleşme ilişkisi olmadığını gösteren boş hipotezler aşağıdaki gibi oluşturulmuştur.

(1) numaralı denklem için;

$$
H_{0}: \delta_{1}=\delta_{2}=0 \quad H_{1}: \delta_{1} \neq \delta_{2} \neq 0
$$

(2) numaralı denklem için;

$$
H_{0}: d_{1}=d_{2}=0 \quad H_{1}: d_{1} \neq d_{2} \neq 0
$$

(3) numaralı denklem için;

$$
H_{0}: h_{1}=h_{2}=0 \quad H_{1}: h_{1} \neq h_{2} \neq 0
$$

(4) Numaralı denklem için;

$$
H_{0}: k_{1}=k_{2}=0 \quad H_{1}: k_{1} \neq k_{2} \neq 0
$$

Eğer her bir model için hesaplanan F-istatistik değeri üst sınır kritik F-istatistiğinden büyükse, eş-bütünleşme ilişkisinin olmadığını ifade eden boşluk hipotezleri reddedilir. Buradan hareketle değişkenler arasında eş-bütünleşme ilişkisi olduğu çıkarımı yapılır. Eğer hesaplanan F-istatistik değerleri alt sınır kritik F-istatistiğinden küçükse boşluk hipotezi kabul edilir. Son olarak, hesaplanan F-istatistiği, üst-sınır ve alt sınır kritik F-istatistik değerleri arasında ise eş-bütünleşme ilişkisi konusunda kararsız kalınır.

Optimal ARDL modelinin seçimi için tahmin, $(p+1)^{k}$, defa tekrarlanır ve optimal model Akaike Bilgi Kriteri (AIC) yardımı ile belirlenir. Burada, $k$ değiş̧ken sayısını ve $p$ değeri de optimal gecikme uzunluğunu göstermektedir. Değişkenler arasında eş-bütünleşme ilişkisinin varlığını gösteren alternatif hipotezin geçerli olması halinde, $\operatorname{ARDL}(n, p)$ uzun dönem model tahmini aşağıdaki denklemler ile tanımlanır: 


$$
\begin{aligned}
& R C I=\beta_{0}+\sum_{i=1}^{n} \beta_{1} R C I_{t-i}+\sum_{i=1}^{p} \beta_{2} F V E_{t-i}+u_{t} \\
& C C I=\theta_{0}+\sum_{i=1}^{n} \theta_{1} C C I_{t-i}+\sum_{i=}^{p} \theta_{2} F V E_{t-i}+e_{t} \\
& T V=\gamma_{0}+\sum_{i=1}^{n} \gamma_{1} T V_{t-i}+\sum_{i=1}^{p} \gamma_{2} F V E_{t-i}+v_{t} \\
& I I P=l_{0}+\sum_{i=1}^{n} l_{1} I I P_{t-i}+\sum_{i=1}^{p} l_{2} F V E_{t-i}+n_{t}
\end{aligned}
$$

Değişkenler arasındaki uzun dönem ilişkilerin belirlenmesinden sonraki aşama, hata düzeltme modeli (ECM) kullanılarak kısa dönemli ilişkilerin araştırılmasıdır. Hata düzeltme modeli (ECM) aşağıdaki denklemler tarafından tanımlanmaktadır:

$$
\begin{aligned}
& \Delta R C I=\alpha_{0}+\sum_{i=1}^{n} \alpha_{1} \Delta R C I_{t-i}+\sum_{i=1}^{n} \alpha_{2} \Delta F V E_{t-i}+\alpha_{3} E C T_{t-1}+e_{t} \\
& \Delta C C I=\alpha_{0}+\sum_{i=1}^{n} \alpha_{1} \Delta C C I_{t-i}+\sum_{i=1}^{n} \alpha_{2} \Delta F V E_{t-i}+\alpha_{3} E C T_{t-1}+e_{t} \\
& \Delta T V=\alpha_{0}+\sum_{i=1}^{n} \alpha_{1} \Delta T V_{t-i}+\sum_{i=1}^{n} \alpha_{2} \Delta F V E_{t-i}+\alpha_{3} E C T_{t-1}+e_{t} \\
& \Delta I I P=\alpha_{0}+\sum_{i=1}^{n} \alpha_{1} \Delta I I P_{t-i}+\sum_{i=1}^{n} \alpha_{2} \Delta F V E_{t-i}+\alpha_{3} E C T_{t-1}+e_{t}
\end{aligned}
$$

Burada, $E C T_{t-1}$ hata düzeltme terimini temsil etmektedir, Ayrica, $e_{t}$ tahmin edilen modelin hata terimidir. Hata düzeltme modelinden elde edilen sonuçlar, kısa dönemde oluşan bir şok sonucu modelin yeniden uzun dönem dengesine dönme hızını vermektedir. Bunun için hata terimine ait katsayı değerinin -1 ile 0 arasında olması ve istatistiksel olarak anlamlı düzeyde bulunması gerekmektedir. 


\subsection{Uygulama Sonuçları}

Modeldeki değişkenler için öncelikli olarak ADF birim kök testi yapılmış ve sonuçlar Tablo 4'de gösterilmiş̧tir. Tablodan anlaşıldığı üzere tüketici güven endeksi (CCI) I(1), reel kesim güven endeksi (RCI) I(0), ticaret hacmi (TV) I(0), finansal kırılganlık endeksi (FVE) I(1) ve uluslararası yatırım pozisyonu (IIP) I(0) olarak elde edilmiştir. Değişkenlerin farklı düzeylerde durağan olması, ARDL tekniği açısından bir sorun teşkil etmemektedir.

Tablo: 4

Birim Kök Testi

\begin{tabular}{|c|c|c|c|}
\hline Değişken & Düzey (ortalama) & Fark (ortalama) & Düzey (trend) \\
\hline CCI & $-2,3052$ & $\mathbf{- 6 , 6 8 9 0} * * *$ & $-2,2770$ \\
\hline RCI & $\mathbf{- 3 , 0 0 2 0} * *$ & $\mathbf{- 7 , 1 0 3 7} * * *$ & $\mathbf{- 3 , 6 5 0 0} * *$ \\
\hline TV & $\mathbf{- 4 , 2 5 3 3} * * *$ & $\mathbf{- 7 , 2 4 3 5} * * *$ & $-\mathbf{4 , 2 6 5 6} * * *$ \\
\hline FVE & $-2,3580$ & $\mathbf{- 5 , 0 2 5 7} * * *$ & $-2,3096$ \\
\hline IIP & $\mathbf{- 5 , 1 1 6 5 * * *}$ & $\mathbf{- 7 , 0 2 1 4} * * * *$ \\
\hline
\end{tabular}

Not: **ve ***, straslyla $\% 5$ ve $\% 1$ anlamlılık düzeylerini ifade etmektedir.

Tahmin edilen modeller için sınır testi sonuçlarını gösteren Tablo 5'e göre reel kesim güven endeksi ile finansal kırılganlık endeksi arasında, ticaret hacmi ile finansal kırılganlık endeksi arasında ve uluslararası yatırım pozisyonu ile finansal kırılganlık endeksi arasında uzun dönemli bir ilişki bulunmaktadır. Her üç modelde de ilişkinin yönü finansal kırılganlık endeksinden diğer değişkenlere doğrudur. Tüketici güven endeksi ile finansal kırılganlık endeksi arasında ise istatistiksel olarak anlamlı bir ilişki görülmemektedir.

\section{Tablo: 5}

\section{Modeller ve Sınır Testi Sonuçları}

\begin{tabular}{|c|c|c|c|c|}
\hline Model & F(CCI; FVE) & F(RCI; FVE) & F(TV; FVE) \\
\hline F-istatistiği & 2,9978 & $\mathbf{9 , 5 9 7 4 * * *}$ & $\mathbf{9 , 4 9 5 0} * * *$ \\
\hline
\end{tabular}

$\mathrm{Bu}$ aşamadan sonra uzun dönem ilişkinin varlığının ortaya konduğu modeller için uzun dönem ARDL tahmin sonuçlarına bakılmalıdır. Tablo 6, bağımlı değişken olarak reel kesim endeksi, ticaret hacmi ve uluslararası yatırım pozisyonunun alındığı durumlar için ARDL uzun dönem sonuçlarını göstermektedir. Bu sonuçlara göre, finansal kırılganlık endeksindeki \%1'lik bir artış, reel kesim güven endeksini \%4,24 oranında arttırmaktadır. Buna karşılık finansal kırılganlık endeksindeki değişimin ticaret hacmi ve uluslararası yatırım pozisyonu üzerindeki uzun dönem etkisi istatistiksel olarak anlamlı görünmemektedir.

Tablo: 6

Uzun dönem ARDL sonuçları

\begin{tabular}{|c|c|c|c|}
\hline & F(RCI; FVE) & F(TV; FVE) & F(IIP; FVE) \\
\hline Sabit & $-0,7355$ & $\mathbf{5 , 6 7 7 6 * * *}$ & $\mathbf{4 , 7 4 6 4 * * *}$ \\
\hline FVE & $\mathbf{4 , 2 4 5 4 * *}$ & $-0,3370$ & $-0,0289$ \\
\hline
\end{tabular}

Not: **ve ***, strastyla \%5 ve \%1 anlamlllk düzeylerini ifade etmektedir. 
Tablo 7, reel kesim güven endeksi için kısa dönem ARDL sonuçlarını ve dengeden sapmanın bir dönemde ne kadarının düzeltildiğini göstermektedir. Reel kesim güven endeksi bağımlı değişken olduğunda, finansal kırılganlık endeksi kaynaklı şokların bir dönemde $\% 37,1$ 'i telafi edilmekte ve sistem yeniden uzun dönem denge yoluna girmektedir.

Tablo: 7

RCI için Kısa Dönem ARDL Sonuçları

\begin{tabular}{|c|c|}
\hline Değisken & Katsayı \\
\hline$\Delta \mathrm{RCI}(-1)$ & 0,0936 \\
\hline$\Delta \mathrm{FVE}$ & $\mathbf{1 , 5 7 6 5 ^ { * * * * }}$ \\
\hline$\Delta \mathrm{ECT}-1$ & $\mathbf{- 0 , 3 7 1 3 * *}$ \\
\hline
\end{tabular}

Not: **ve ***, strasılla $\% 5$ ve $\% 1$ anlamlllk düzeylerini ifade etmektedir.

Tablo 8, ticaret hacmi için kısa dönem ARDL sonuçlarını ve dengeden sapmanın bir dönemde ne kadarının düzeltildiğini göstermektedir. Bağımlı değişkenin ticaret hacmi olması durumunda finansal kırılganlık endeksi kaynaklı şokların bir dönemde \%27,7'si \%10 hata payı ile düzeltilmekte ve sistem yeniden uzun dönem denge yoluna girmektedir.

Tablo: 8

TV için Kısa Dönem ARDL Sonuçları

\begin{tabular}{|c|c|}
\hline Değisken & Katsayı \\
\hline$\Delta \mathrm{FVE}$ & $-0,0936$ \\
\hline $\mathrm{ECT}_{-1}$ & $\mathbf{- 0 , 2 7 7 7 ^ { * }}$ \\
\hline
\end{tabular}

Not: *, \%10 anlamlılık düzeyini ifade etmektedir.

Tablo 9'da ise finansal kırılganlık endeksi kaynaklı şokların, uluslararası yatırım pozisyonu üzerindeki etkisinin \%92'sinin aynı dönem içinde giderilmekte olduğu ve sistemin dengeye yaklaştığı görülmektedir.

Tablo: 9

IIP için Kısa Dönem ARDL Sonuçları

\begin{tabular}{|c|c|}
\hline Değişken & Katsayı \\
\hline$\Delta \mathrm{FVE}$ & $-0,0266$ \\
\hline ECT -1 & $\mathbf{- 0 , 9 2 1 5 * * *}$ \\
\hline
\end{tabular}

Not: ***, \%1 anlamlılık düzeyini ifade etmektedir.

\section{Sonuç}

$\mathrm{AB}$ ile Türkiye arasında uzun yıllardan beri süregelen ekonomik ilişkiler yalnızca mal ve hizmet ticareti değil sermaye ve finans akımları çerçevesinde de kendini hissettirmektedir. Türkiye'nin toplam ihracat ve ithalatının coğrafik dağılımı dikkate alındığında Avrupa Birliği ülkelerinin \%50’ye yakın bir paya sahip olduğu görülmektedir. Ayrıca, Türkiye'ye gelen doğrudan yabancı yatırımların da yaklaşık 2/3'ü AB ülkelerinden gelmektedir. Benzer durum portföy yatırımları açısından da geçerlidir. Dolayısıyla, bu kadar geniş ve yoğun entegrasyon içerisinde olan bu iki ekonominin birinde ortaya çıacak bir gelişmenin diğerini etkileme potansiyelinin de yüksek olması beklenmelidir. 
Bu çalışmada, küresel kriz sonrasında Euro bölgesinde ortaya çıkan borç krizinin Türkiye'yi hangi kanallardan etkilediği ve özellikle hangi kanalın daha güçlü olarak kendini hissettirdiği araştırılmıştır. Çalışmada üç önemli potansiyel etki kanalı üzerinde durulmuştur. Birincisi, küresel bankacılık ve finans sistemlerinin entegrasyonu sonucunda ortaya çıkan sermaye ve finans kanalıdır. İkincisi, dış talepte meydana gelen olası düşüşleri yansıtan diş ticaret kanalıdır. Sonuncusu ise küresel ortamda oluşan olumsuz koşullar nedeniyle ekonomiye duyulan güvendeki azalmayı ifade eden beklentiler kanalıdır.

Borç krizini temsil etmek üzere çalışmada öncelikle, Euro bölgesi finansal kırılganlık endeksi oluşturulmuştur. Daha sonra, ARDL (Sınır Testi) yöntemi kullanılarak bu finansal kırılganlık endeksi (FVE) ile borç krizinin Türkiye ekonomisine yayılma kanallarından sermaye ve finans kanalını temsilen uluslararası yatırım pozisyonu açığı (IIP), dış ticaret kanalını temsilen toplam dış ticaret hacmi (TV) ve beklentiler kanalını temsilen de tüketici güven endeksi (CCI) ve reel kesim güven endeksi (RCI) değişkenleri arasındaki ilişki analiz edilmiştir.

Tahmin edilen modellerin sınır testi sonuçlarına göre finansal kırılganlık endeksi ile reel kesim güven endeksi, ticaret hacmi ve uluslararası yatırım pozisyonu arasında uzun dönemli bir ilişki söz konusudur. Ayrıca, ilişkinin yönünün finansal kırılganlık endeksinden diğer üç değişkene doğru olduğu tespit edilmiştir. Bu analiz sonuçları, söz konusu borç krizinin her üç kanal vasıtasıyla da Türkiye’yi etkilediğini göstermektedir. Özellikle, finansal kırılganlık endeksinden reel kesim endeksine doğru olan uzun dönemli ilişkinin istatistiksel olarak anlamlı bulunması, beklentiler kanalının dış ticaret ile sermaye ve finans kanalına kıyasla daha ön planda olduğunu vurgulamaktadır. Diğer taraftan, beklentiler kanalında yer alan tüketici güven endeksi ile Avrupa borç krizi arasında anlamlı bir ilişki bulunamamıştır. Bu durum, tüketicilerin genel ekonomik durum ve istihdam olanakları konusundaki beklentilerinin borç krizi karşısında önemli bir değişim göstermediğini ve dolayısıyla da krizin Türkiye'ye bu kanaldan yayılımını engellediğini ifade etmektedir. Yakın ve Ortadoğu ülkeleriyle gerçekleştirilen ekonomik ilişkilerdeki gelişmenin tüketici beklentilerini olumlu yönde etkilemesi bunun nedenlerinden biri olarak düşünülebilir. Ancak bu noktada daha detaylı araştırmaların yapılması daha doğru sonuçların elde edilmesi açısından önem arz etmektedir. Aynı şekilde, Türkiye'nin son yıllarda gerek mal ve hizmet akımları gerekse sermaye akımları açısından yeni pazar arayışları içerisine girmesinin, borç krizinden dış ticaret ve sermaye-finans kanalı yoluyla daha az etkilenmesine neden olduğunu söylemek de mümkündür.

Beklentiler kanalında yer alan reel kesim güven endeksinin istatistiksel olarak anlamlı olması, bu endeksin üreticilerin yatırım yapma isteğinin ve risk alma eğilimlerinin bir göstergesi olması nedeniyle Türkiye'de makroekonomik istikrarın sağlanmasının ve yatırımcı güveninin geliştirilmesinin diğer ülkelerde ortaya çıkacak krizlerin etkilerini zayıflatacağına vurgu yapmaktadır. Dolayısıyla makroekonomik politikaların yatırım 
ortamını iyileştirici ve teşvik edici şekilde planlanmasının ve uygulanmasının, uluslararası krizler karşısında Türkiye ekonomisinin direncini artıracağını söylemek mümkündür.

\section{Kaynaklar}

Acharya, V.V. \& M. Richardson (2009), "Causes of the Financial Crisis", Critical Review, 21(2-3), 195-203.

Adom, P.K. \& W. Bekoe \& S.K.K Akoena (2012), "Modeling Aggregate Domestic Electricity Demand in Ghana: An Autoregressive Distributed Lag Bounds Cointegration Approach", Energy Policy, (42), 530-537.

Akaike, H. (1971), "Statistical Predictor Identification”, Annals of the Institute of Statistical Mathematics, (22), 203-217.

Alantar, D. (2008), “Türkiye Finans Yöneticileri Vakfı”, Maliye Finans Yazıları, Ekim(81), 1-10.

Aysan, A.F. \& E. Ermişoğlu (2013), "Eurozone Debt Crisis and its Effects on Turkish Economy", Munich Personal RePEc Archive, MPRA Paper No, 50501.

Berberoğlu, B. (2011), “2008 Global krizinin Türkiye ve Avrupa Birliği’ndeki Etkilerinin Kümeleme Analizi ile İncelenmesi”, Anadolu Üniversitesi Sosyal Bilimler Dergisi, 11(1), 105-130.

Crotty, J. (2009), "Structural Causes of the Global Financial Crisis, A Critical Assessment of the New Financial Architecture", Cambridge Journal of Economics, (33), 563-580.

Çınar, B. \& Ö. Erdoğan \& T.P. Gürgür (2010), "Küresel Kriz, Etkileşim Kanalları ve Türkiye Ekonomisi”, Ekonomi Notlar, TCMB, 2010-7.

Çiftçi, D. \& İ. Çeviş (2012), "European Union Debt Crisis and Credit Default Swaps, in Light of Global Financial Crisis", İktisat İsletme ve Finans, 27(321), 57-84.

Doğru, B. (2012), “ABD ve AB Bölgesindeki Bir Finansal Krizin Türkiye’ye Etkileri: Cari Açık Üzerine Bir Uygulama”, Dumlupınar Üniversitesi Sosyal Bilimler Dergisi, (33), 113128.

Duasa, J. (2007), "Determinants of Malaysia Trade Balance: An ARDL Bound Testing Approach", Global Economic Review, 36(1), 89-102.

Engle, R.F. \& C.W.J. Granger (1987), "Co-integration and Error Correction: Representation, Estimation, and Testing", Econometrica, (55), 391-407.

Erer, E. \& D. Erer (2012), “AB Borç Krizinin Gelişmekte Olan Ülkeler ve Türkiye Üzerine Etkisi: Panel Veri Analizi”, Debt Dynamics, Financial Instability and The Great Recession, International Conference of Economics, The Turkish Economic Association, ICE-TEA 2012, November 1-3, 2012 İzmir-Turkey, <http://www.teacongress.org/>, 13.06.2017.

Eurostat, <http://epp.eurostat.ec.europa.eu>, 16.01.2017.

Gros, D. \& T. Mayer (2010), "How to Deal with Sovereign Default in Europe: Create The European Monetary Fund Now!", CEPS Policy Brief, No: 202.

IMF (2010), "How Did Emerging Markets Cope in The Crisis?", IMF Policy Paper, <https://www.imf.org/external/np/pp/eng/2010/061510.pdf>, 06.02.2017.

Iş1k, N. \& T. Tönen (2010), “Türev Ürünlerinin, 2008, Küresel Finansal Krizindeki Rolü”, Turgut Özal Uluslararası Ekonomi ve Siyaset Kongresi- I Küresel Krizler ve Ekonomik Yönetişim, 836-866. 
Johansen, S. (1991), "Estimation and Hypothesis Testing of Cointegration Vectors in Gaussian Vector Autoregressive Models", Econometrica, 59(6), 1551-1580.

Kaya, N. \& Y. Barlas \& K. Kalafatçılar (2011), "Euro Bölgesi Çevre Ülkelerinin Krılganlıkları ve Bankacılık Sektörlerinin Karşılıklı Duyarlılıkları”, Ekonomi Notları, TCMB, 2011-9.

Kibritçioğlu, A. (2011a), “Avro Bölgesindeki Ülkelerin Güncel Borç Krizi”, İktisat ve Toplum Dergisi, (10), 30-41.

Kibritçioğlu, A. (2011b), "The Components and Complexity of the Global Economic Crisis of 20062011", Munich Personal RePEc Archive, MPRA Paper No, 33515.

Kibritçioğlu, A. (2011c), "Current Sovereign Debt Crisis in Eurozone Countries”, Munich Personal RePEc Archive, MPRA Paper No, 33528.

Kutlay, M. (2011), “Krizdeki Birlik Euro Bölgesinin Borç Sarmalı ve AB'nin Geleceği”, USAK Raporlart, Rapor No, 11-01, Mart 2011.

Küçüksaraç, D. \& P. Özlü \& D. Ünalmış (2012a), "Küresel Kriz, Avrupa Borç Krizi ve Gelişmekte Olan Piyasalarda Bulaşıcılık Etkisi”, Ekonomi Notları, TCMB, 2012-4.

Küçüksaraç, D. \& P. Özlü \& D. Ünalmış (2012b), "Küresel Kriz, Avrupa Borç Krizi ve Gelişmekte Olan Piyasalarda Bulaşıcılık Etkisi”, Central Bank Review, 12 (July), 25-35.

Lee, M. \& D. Park \& A. Abdon \& G.B. Estrada (2013), "Economic Impact of Eurozone Sovereign Debt Crisis on Developing Asia", Asian Development Bank (ADB) Economics Working Paper Series, No: 336.

Mishkin, F. (2000), "Financial Policies and The Prevention of Financial Crisis in Emerging Market Countries, NBER Working Papers, September, No: 3.

Murphy, A. (2008), "An Analysis of The Financial Crisis of 2008: Causes and Solutions”, Working Paper, Social Science Research Network <https://papers.ssrn.com/sol3/papers.cfm?abstract id=1295344>, 16.01.2017.

Neri, S. \& T. Ropele (2015), "The Macroeconomic Effects of The Sovereign Debt Crisis in The Euro Area, Banca D'İtalia, Temi di Discussion, Working papers, Number 1007, March 2015.

Pesaran, M.H. \& Y. Shin (1998), “An Autoregressive Distributed-lag Modelling Approach to Cointegration Analysis", Econometric Society Monographs, 31, 371-413.

Pesaran, M.H. \& Y. Shin \& R. Smith (2001), "Bounds Testing Approaches to the Analysis of Level Relationship", Journal of Applied Econometrics, 16(3), 289-326.

Rengasamy, E. (2012), “Sovereign Debt Crisis in The Euro Zone and Its Impact on the BRICS's Stock Index Returns and Volatility", Economics and Finance Review, 2(2), 37-46.

Rose, A.K. \& M.M. Spiegel (2009), "Cross-Country Causes and Consequences of the 2008 Crisis: Early Warning”, Working Paper, 15357, National Bureau of Economic Research, Cambridge.

Stracca, L. (2013), "The Global Effects of the Euro Debt Crisis, European Central Bank (ECB)", Working Paper Series, No, 1573.

TCMB (2012a), Tüketici Ĕgilim Anketi ve Tüketici Güven Endeksi-Genel Açıklama, <http://www.tcmb.gov.tr/tuketanket/metodoloji.pdf>, 16.01.2017.

TCMB (2012b), Reel Kesim Güven Endeksi (MBRKGE)'ne İlişkin Yöntemsel Açılama, <http://www.tcmb.gov.tr/ikt-yonelim/RKGE-YontemselAciklama.pdf>, 16.01.2017. 